San Jose State University

SJSU ScholarWorks

Master's Theses

Master's Theses and Graduate Research

1992

\title{
Benthic invertebrates living in macroalgal mats on intertidal mudflats of Elkhorn Slough, California
}

Jane King Allen

San Jose State University

Follow this and additional works at: https://scholarworks.sjsu.edu/etd_theses

\section{Recommended Citation}

Allen, Jane King, "Benthic invertebrates living in macroalgal mats on intertidal mudflats of Elkhorn Slough, California" (1992). Master's Theses. 372.

DOI: https://doi.org/10.31979/etd.m4p3-3a38

https://scholarworks.sjsu.edu/etd_theses/372

This Thesis is brought to you for free and open access by the Master's Theses and Graduate Research at SJSU ScholarWorks. It has been accepted for inclusion in Master's Theses by an authorized administrator of SJSU ScholarWorks. For more information, please contact scholarworks@sjsu.edu. 


\section{INFORMATION TO USERS}

This manuscript has been reproduced from the microfilm master. UMI films the text directly from the original or copy submitted. Thus, some thesis and dissertation copies are in typewriter face, while others may be from any type of computer printer.

The quality of this reproduction is dependent upon the quality of the copy submitted. Broken or indistinct print, colored or poor quality illustrations and photographs, print bleedthrough, substandard margins, and improper alignment can adversely affect reproduction.

In the unlikely event that the author did not send UMI a complete manuscript and there are missing pages, these will be noted. Also, if unauthorized copyright material had to be removed, a note will indicate the deletion.

Oversize materials (e.g., maps, drawings, charts) are reproduced by sectioning the original, beginning at the upper left-hand corner and continuing from left to right in equal sections with small overlaps. Each original is also photographed in one exposure and is included in reduced form at the back of the book.

Photographs included in the original manuscript have been reproduced xerographically in this copy. Higher quality $6 "$ " 9 9" black and white photographic prints are available for any photographs or illustrations appearing in this copy for an additional charge. Contact UMI directly to order.

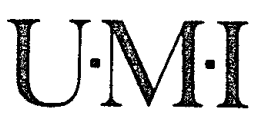

University Microlilms International

A Bell \& Howell Information Company

300 North Zeeb Road. Ann Arbor, Ml 48106-1346 USA

$313.761-4700 \quad 800: 521-0600$ 

Order Number 1350066

Benthic invertebrates living in macroalgal mats on intertidal mudflats of Elkhorn Slough, California

Allen, Jane King, M.S.

San Jose State University, 1992

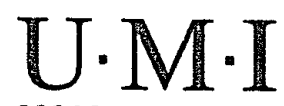

300 N. Zceb Rd.

Ann Arbor, MI 48106 



\title{
BENTHIC INVERTEBRATES LIVING IN MACROALGAL MATS ON INTERTIDAL MUDFLATS OF ELKHORN SLOUGH, CALIFORNIA.
}

\author{
A Thesis \\ Presented to \\ The Faculty of Moss Landing Marine Laboratories \\ San Jose State University
}

In Partial Fullfilment

of the Requirements for the Degree

Master of Science

\author{
By \\ Jane King Allen \\ August, 1992
}


APPROVED FOR THE DEPARTMENT OF BIOLOGICAL SCIENCES

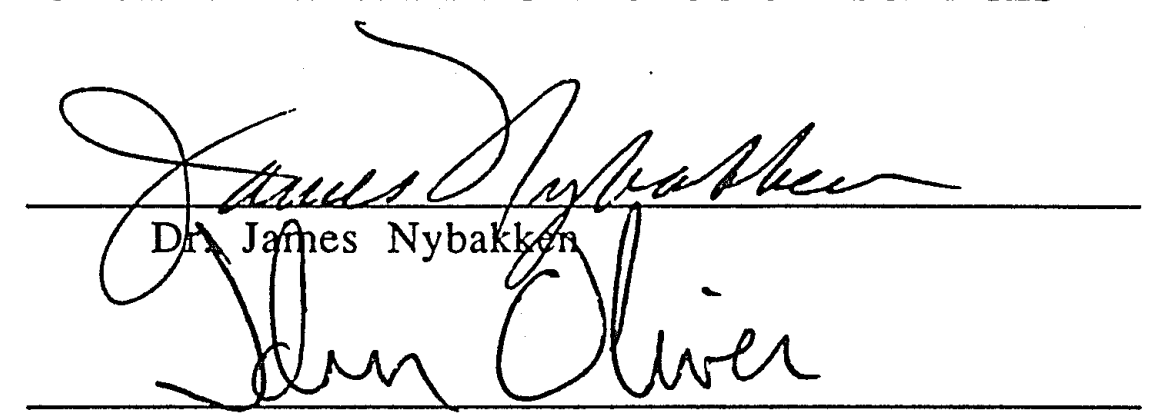

Dr. John Oliver

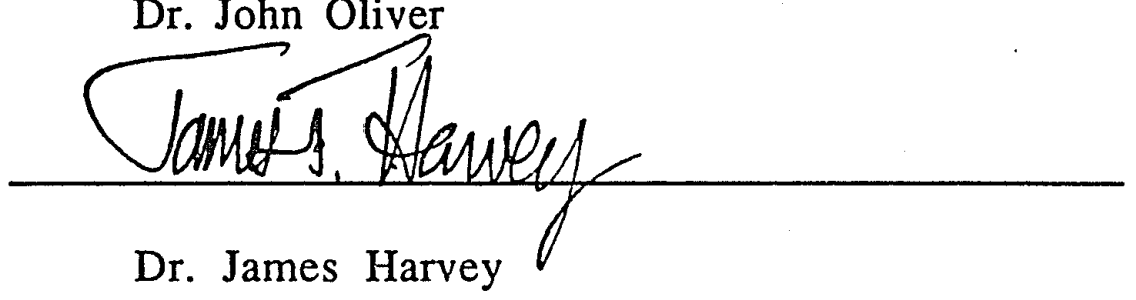

APPROVED FORJTHE UNIYERSITY

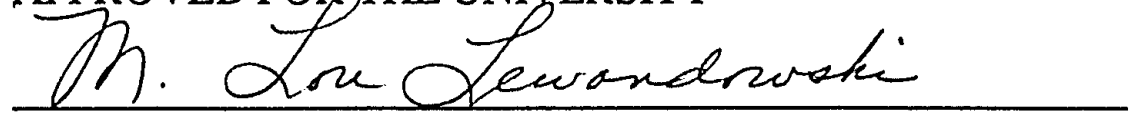




\section{ABSTRACT \\ BENTHIC INVERTEBRATES LIVING IN MACROALGAL MATS ON INTERTIDAL MUDFLATS OF ELKHORN SLOUGH, CALIFORNIA}

by Jane King Allen

Extensive mats of macroalgae harbor a dense assemblage of amphipod crustaceans on the intertidal mudflats of Elkhorn Slough. The green algae Enteromorpha spp., covers large areas on the mudflats during spring and summer; while, Gracilaria lemaneiformis is the dominant alga in fall and winter. Amphipod crustaceans were significantly more abundant within algal mats compared underlying sediment and areas free of algae. Polychaete worms were more numerous in underlying sediment below algal mats compared with algal mats; however, abundances were similar in algal covered areas (mat and underlying sediment) and algal-free mudflats. The seasonal abundance of crustaceans and annelids was greater in fall compared with other seasons.

During field experiments large numbers of amphipods colonized artificial and natural substrates. While algae appears to be of value as a physical substrate, the amphipod, Allorchestes angusta, consumed Enteromorpha spp. in laboratory experiments, indicating the additional food value of these algae. 


\section{ACKNOWLEDGMENTS}

I am deeply grateful tc the wonderful faculty at Moss Landing Marine Laboratories who have inspired and challenged me during my studies there. I am especially grateful to Dr. John Oliver who helped in all aspects of my thesis research, and for his friendship, and guidance in developing a keener sense of awe for the natural world. Thanks to Mark Silberstein, who first inspired me about Elkhorn Slough and helped with invertebrate species identification and the logistics of working in the Elkhorn Slough National Estuarine Research Reserve. A special thanks to Sheila Baldridge, Lynn McMasters, Lisa Uttal Cooke, Gail Johnston, Peter Slattery, Kim Burdett, Dr. Greg Cailliet, Jim Oakden, Jo Guerrero, Bill Kennann, Rikk Kvitek, Janey Burger Fadley, Kathy Conlan, Marth Kenner (easter grass) and Tom Okey. Also to Jim Watenatee, Roger Phillips and Arlene Breise at the Monterey Bay Aquarium for their support in many ways.

I am very grateful to my committee members, Dr. James Nybakken, Dr. Jim Harvey and Dr. John Oliver for their thoughtful comments to my thesis drafts.

Finally I owe the greatest thanks to my parents, Coralin and Gordon King, who have been there for me with love and unconditional support at all times! Thanks to Neil Allen, my husband, for his patience during this long process of finishing my masters degree. A special thanks to my grandmother, Vada Marr Beard, for her support.

Partial funding for my research was kindly provided by the Earl and Ethel Meyers Foundation, the Elkhorn Slough Foundation and the California State Lottery Community grant. 


\section{TABLE OF CONTENTS}

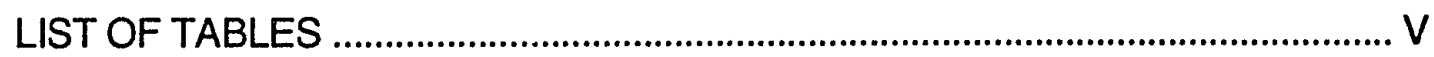

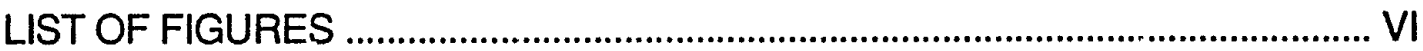

INTRODUCTION ..................................................................................................

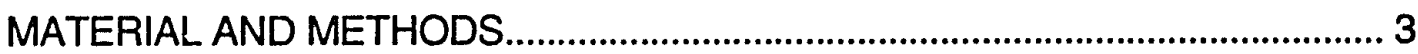

Study area …............................................................................................ 3

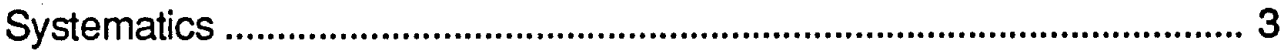

Sampling and sample treatment ................................................................ 4

High-tide sampling................................................................................... 5

Field experiment ........................................................................................ 6

Feeding experiment ..................................................................................... 8

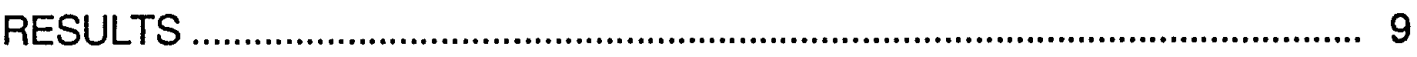

Macroalgae seasonal patterns ............................................................. 9

Invertebrate communities ........................................................................ 9

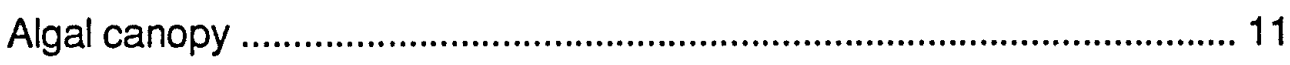

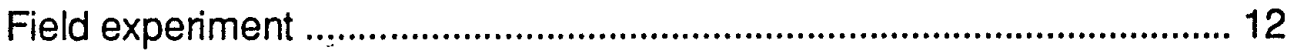

Feeding experiment ................................................................................... 13

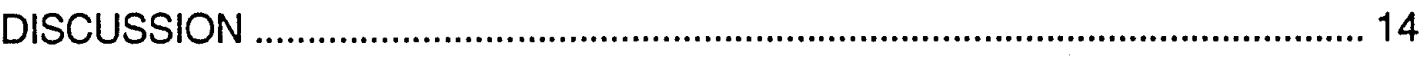

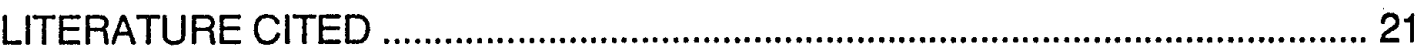

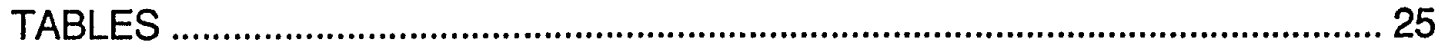

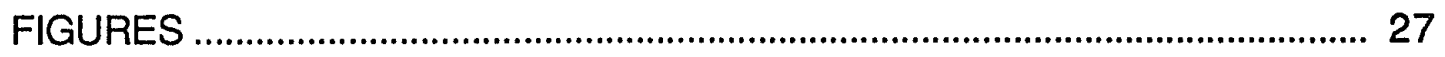

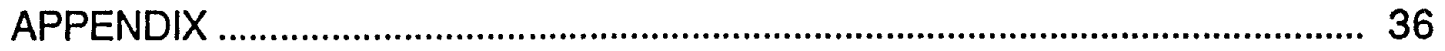




\section{LIST OF TABLES}

Table

Page

1. Comprehensive list of the most abundant benthic invertebrates within algae, underlying sediment below algae and algal-free mudflats

2. Mean number of invertebrates within algal canopy and underlying sediment below algae at high-tide 26 


\section{LIST OF FIGURES}

Figure Page

i. Map of Elkhorn Slough showing study sites A, B and C .................... 27

2. Percent macroalgal cover on the site A mudflat from

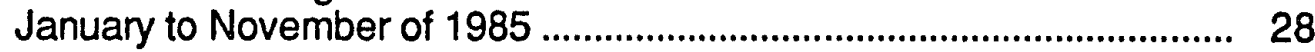

3. Abundance of amphipod crustaceans and polychaete worms within algal mat, underneath algal mat and in algal-free mudflat from June 1984 to November 1985

4. Total abundance of amphipods and polychaetes within all habitats from June 1984 to November 1985

5. Numbers of Allorchestes angusta and Corophium spp. amphipods within algal mat, underneath algal-mat and in algal-free mudflat

6. Numbers of Streblospio benedicti and Capitella capitata worms within algal mat, underneath algal-mat and in algal-free mudflat

7. Numbers of oligochaete worms within algal mat, underneath algal-mat and in algal-free mudflat

8. Amphipod numbers colonizing defaunated natural algae, plastic strips and yarn on an algal-free mudflat in November, 1987

9. Amphipod numbers in a natural algal mat and an area where algae was experimentally removed in November, 1987 


\section{INTRODUCTION}

Macroalgae form extensive mats on intertidal mudflats in estuarine and coastal systems. Unlike the well studied seagrass communities, however, relatively little is known about the benthic animals inhabiting these algal mats. Dense blooms of the green macroalgae, Enteromorpha spp. and Ulva spp., cover large areas on intertidal mudflats during spring and summer along the west coast of the United States (Shellem \& Josselyn 1982; Price \& Hylleberg 1982; Pregnall \& Rudy 1985). Similar algal mats are known from many other coastal systems around the world (Bliding 1963). Numerous studies within seagrass beds indicated increased abundance and species richness of benthic invertebrates within seagrass beds compared with adjacent unvegetated areas (Orth et al. 1984; Stoner 1980a; Heck and Orth 1980; Kitting et al. 1984; Edgar 1990). Increased invertebrate density may be a result of a physical refuge from predation within seagrass beds (Virnstein et al. 1983; Summerson and Peterson 1984). Levings (1980) and Zimmerman \& Minello (1984) documented elevated numbers of amphipod crustaceans in seagrass habitats compared with unvegetated mudflats. Macroalgal mats occur at a higher tidal elevations than seagrass beds, therefore, different physical factors affect the associated invertebrate fauna.

The intertidal mudflats of Elkhorn Slough cover an area of over 420 acres (Browning 1972), and are largely covered with dense mats of Enteromorpha spp. algae in spring and summer (covering over 70 percent of the South Marsh study area). In eutrified estuarine systems, the abundance and species diversity of fauna were less under dense Enteromorpha spp. cover than in algal-free areas (Nicholls et al. 1981; Tubbs \& Tubbs 1983; Hull 1987). 
This study of the intertidal mudflats of Elkhorn Slough addresses the following questions:

1. Is there a difference in abundance and species distribution of macroinvertebrates within algal mats, in underlying sediment below mats, and in areas free of algal cover?

2. What is the seasonal pattern of distribution and abundance of macroinvertebrates in these habitats?

3. What is the species composition and seasonal pattern of macroalgae on the study area mudflat?

4. What factors affect macroinvertebrate abundance? 


\section{MATERIALS AND METHODS}

\section{Study Area}

The primary study site was the South Marsh within the Elkhorn Slough National Estuarine Research Reserve (E.S.N.E.R.R.; Fig. 1). This marsh was originally a wetland which was diked and drained for pasture, and returned to tidal flow in October of 1983. Most of the 2,500 acres is comprised of wide mudflats at approximately 0.9 meters above mean lower low water (MLLW), which is below the elevation of salt marsh habitat dominated by Salicornia virginica. These flats harbor a dense growth of macroalgae, primarily Enteromorpha spp., during much of the year. All seasonal sampling was conducted on the mudflat just north of the entrance to the South Marsh (Fig. 1, site A). The sediment in surrounding mudflats in the mid-section of the slough are a silty mud, being poorly sorted with a medium diameter of $0.002 \mathrm{~mm}$ (Nybakken et al. 1977).

\section{Systematics}

Norris (1970) identified five species and one subspecies of Enteromorpha in Elkhorn Slough, which included; E. intestinalis, E. linza, E. clathrata, E. clathrata var. crinita, E. flexuosa and E. prolifera. Due to the difficulty in distinguishing the various species, no attempt was made to separate the species and they are referred to as Enteromorpha spp. The amphipod crustaceans Corophium insidiosum and C. acherusicum were grouped together as Corophium spp., because the females of the two species are indistinguishable (Smith and Carlton, 1975). 


\section{Sampling and Sample Treatment}

Percentage algal cover and species composition of macroalgae on the mudflat was estimated five times from January 1985 to November 1985. Quadrats $(25 \times 25 \mathrm{~cm})$ were placed haphazardly on the mudflat $(\mathbb{N}=50$ per survey) during each sampling period.

To assess effects of algal mats on associated fauna, species composition and abundance of invertebrates found within algal covered areas (algal mat and underlying sediment), were compared with algal-free areas through seasonal sampling. Invertebrates were sampled during seven sampling periods from June 1984 to November 1985. Three habitats were sampled: macroalgal mats, underlying sediment below the mats, and sediments in unvegetated areas. Five replicate hand-held cores (area $=0.002 \mathrm{~m}^{2}$ ) were taken from each habitat and contents washed over a $0.5 \mathrm{~mm}$ sieve. Organisms retained on the sieve were preserved in a $4 \%$ solution of formaldehyde, which were transferred to $70 \%$ alcohol after 24 hours. The vegetated mudflat samples were taken where there was at least 50 percent algal cover. The overlying algal mat was peeled away from the core and washed over a $0.5 \mathrm{~mm}$ sieve. In June 1984, algae and underlying sediment were processed together. Animals were identified to the lowest possible taxon and enumerated.

Differences between number of amphipods or polychaetes within algae and within underlying sediments of the same core were tested using a paired ttest. Differences in numbers of amphipods and polychaetes found in algal covered areas (mat and underlying sediment) and algal-free areas were determined using unpaired t-tests. Differences in numbers of polychaetes among seasons were determined using an ANOVA, followed by a Ryan's Q-test 
(Day \& Quinn, 1989). There was a significant interaction between season and substrates for seasonal abundance of amphipods using an ANOVA; therefore, seasonal amphipod abundance was compared using a Ryan's $Q$ test.

\section{High-Tide Sampling}

Invertebrates within the floating Enteromorpha spp. canopy and associated underlying sediment were sampled to evaluate the species distribution and abundance during high tide. On June 4,1989, samples of floating Enteromorpha spp. (which was attached to the sediment below) and underlying sediment were taken from a canoe just north of Kirby Park (Fig. 1, site C). A $20 \mathrm{~cm}$ diameter PVC ring (area $=0.0314 \mathrm{~m}^{2}$ ) fitted with a net of 0.5 $\mathrm{mm}$ mesh screen $30 \mathrm{~cm}$ in length was swept along the surface water horizontally for approximately $70 \mathrm{~cm}$. The depth of the water column was approximately $75 \mathrm{~cm}$. The total volume of water sampled during each sweep was $0.022 \mathrm{~m}^{3}$. Algae samples were washed over a $0.5 \mathrm{~mm}$ mesh sieve, and the animals retained were sorted under a dissecting microscope, preserved in $4 \%$ formaldehyde, and identified to the lowest taxon possible. Samples of bottom sediment were washed through a $0.5 \mathrm{~mm}$ mesh screen and processed like the algal samples. Data from net samples were transformed to the same area as the core samples (area $=0.002 \mathrm{~m}^{2}$ ) by dividing by 70 to adjust for the $5 \mathrm{~cm}$ core size and multiplying by 4.8 to include the water column sampled above the core sample.

A Mann-Whitney $U$ test was used to evaluate the difference in numbers of amphipod crustaceans and oligochaete worms within the algae and the associated underlying sediment. 


\section{Field Experiment}

A field experiment using artificial (non-nutritional) substrates and natural algae was conducted to test the importance of algae as a structural habitat for amphipods. Eighteen enclosures were established on a relatively bare mudflat at approximately the same tidal level (about $0.5 \mathrm{~m}$ above MLLW) along the main channel of Elkhorn Slough in the E.S.N.E.R.R. (Fig. 1, site B). Substrates were placed within these enclosures and monitored from 3 to 7 December, 1987. Enclosures were constructed of $6 \mathrm{~mm}$ mesh wire, formed into cylinders $62 \mathrm{~cm}$ high with a diameter of $55 \mathrm{~cm}$. Enclosures were placed on the mudflat haphazardly, with each of the replicate treatments interspersed (Hulbert 1984). Enclosures were pushed approximately $10 \mathrm{~cm}$ into the sediment to secure them in place.

The experimental comparison included six treatments with three replicates.

1) Algal-free : locations naturally containing no macroalgae were enclosed.

2) Natural algae: areas with greater than $50 \%$ algal cover were enclosed.

3) Algae removed: all algae were removed from enclosed areas with greater than $50 \%$ Enteromorpha spp. cover to create artificial algalfree areas

4) Natural algae defaunated: algae were brought to the laboratory and rinsed in clean seawater. All animals were removed by bubbling carbon dioxide through the algae for 20 minutes. Anaesthetized animals dropped out. 
4) The algae were subsampled and examined to confirm the absence of animals and placed back onto the mudflat within enclosures.

5) Artificial algae (plastic): imitation algal mats were formed by tying together bunches of thin green plastic stands and placed within enclosures.

6) Artificial algae (yarn): Yarn was added within enclosures on the second day of the experiment because the plastic strips shed water, unlike natural algae.

Natural and artificial algae in treatments 4-6 were secured to the substrate by pushing strands into the sediment. These treatments maintained their original cover for the duration of the experiment.

One core (area $=0.002 \mathrm{~m}^{2}$ ) was taken from each of the three replicates for treatments 1 (algal-free), 2 (natural algae) and 3 (algae removed) when the enclosures were originally placed on the mudflat. Subsequently, one core was taken from each of the three replicates for each of the six treatments every 24 hours for 3 days. Samples were taken of the substrate only (algae or artificial algae) for treatments $2,4,5$, and 6 . The samples taken within algal-free treatments and algae removed treatments were sediment core samples. All cores were sieved through a $0.5 \mathrm{~mm}$ mesh screen, and organisms preserved in $4 \%$ formaldehyde. Amphipods were identified to species and enumerated.

After two days in the field, mean number of amphipods colonizing the yarn and plastic substrates were compared with natural defaunated algae using a Kruscal Wallis non parametric ANOVA test. A Mann Whitney $U$ test was 
used to compare mean number of amphipods colonizing natural algal plots with treatments where algae were removed.

\section{Laboratory Feeding Experiment}

A feeding experiment was conducted in November of 1989 , to evaluate the role of Enteromorpha as a food source for Allorchestes angusta, the most abundant amphipod in this study. Amphipods were collected north of Kirby Park from floating Enteromorpha spp. mats (Fig 1, site C). Amphipods were removed from the algae and placed in nylon mesh t-buoys in an aerated aquarium with running filtered seawater at the Montery Bay Aquarium's research laboratory. The Enteromorpha spp. devoid of animals was placed in an aquarium to be used in the feeding experiment.

Whole healthy strands of algae were blotted dry on paper towels for half an hour. Wet weight was measured to the nearest 0.0001 gram using a Mettler AE 163 scale. Three strands of algae were placed in each of 10 glass petri dishes (10 cm diameter), which were half filled with filtered seawater. Amphipods were starved prior to the experiment for two days. Fourteen Allorchestes angusta amphipods were placed in five dishes, the other five were controls without amphipods. The two treatments were interspersed on a seawater table with running seawater surrounding all dishes. Amphipods were removed from the Enteromorpha spp. after 24 hours, recounted and preserved in $70 \%$ ethanol. Three Allorchestes angusta were dissected under a Wild dissecting microscope and the crop examined for Enteromorpha spp. Algae were weighed at the end of the experiment to determine loss from feeding. 


\section{RESULTS}

\section{Macroalgae Seasonal Patterns}

The species composition and percent cover of macroalgae on the intertidal mudflats of the South Marsh showed dramatic seasonal patterns. Enteromorpha spp. developed a thick, persistent mat by early spring, and covered most of the study area throughout the summer, reaching a peak cover of $72 \%$ in May, 1985 (Fig. 2). As a result, most macrofauna sampled in algal covered areas were taken within the Enteromorpha mat. The exceptions were October and December 1984 and November 1985 when Gracilaria lemaneiformis was the most common alga (Fig. 2). Gracilaria lemaneiformis was dominant during winter months, reaching a peak cover of $13.3 \%$ in November 1985. The red alga Polysiphonia pacifica was least abundant, and was not present in quadrat sampling.

\section{Invertebrate Communities}

Species composition of macrofaunal invertebrates within algal covered and algal-free areas was similar, but relative abundances were quite different (Table 1). The most numerically abundant animal found throughout the study was the polychaete worm Streblospio benedicti, followed by oligochaete worms and the polychaete, Capitella capitata. Other less abundant polychaetes were Eteone californica, Armandia brevis, and Polydora socialis. Nematodes were occasionally abundant but were not retained adequately by the $0.5 \mathrm{~mm}$ mesh screen. The most abundant crustaceans were the gammarid amphipods, Allorchestes angusta and two indistinguishable species of Corophium, C. insidiosum and $C$. acherusicum (Table 1). The other crustaceans occasionally 
found in the area were the amphipods, Grandidierella japonica and Ampithoe valida, podocopid ostracods, and harpacticoid copepods. The copepods were not included in the data analysis because they were not sampled adequately by the $0.5 \mathrm{~mm}$ mesh screen. All other infaunal groups were rare. The major crustacean and annelid groups in the study area were similar to those reported from the adjacent mudflats in Elkhorn Slough (Nybakken et al. 1977).

The greatest differences in species abundance in the algal covered versus algal-free areas involved the amphipod crustaceans. Amphipods were significantly more abundant in the algal mat compared with the sediment below the mat (paired t-test, $R<.0001, n=30$ ) for all months where sampling separated the two (Fig. 3). The total number of amphipod crustaceans was significantly higher in areas covered with algae (algal mat and infauna) compared to areas free of algal cover ( $t$-test, $D<.0001, n=30$ ). However, in November of 1985, the number of Corophium spp. was slightly higher in the algal-free area compared to the algal mat and under the mat (Fig. 5), although this difference was not significant (t-test: $\mathrm{p}>.2369$ out vs algae; $\mathrm{R}<.1764$ out vs under, $\mathrm{n}=5$ ).

There was a clear trend towards higher numbers of amphipods in the fall compared to summer, spring, and winter (Fig. 4). The number of amphipods in October, 1984 and November, 1985 was significantly higher than in all other months [Ryan's $Q$ test (Day and Quinn, 1989), $\mathrm{D}<0.05, \mathrm{CV}=8.651, \mathrm{D}=7$ ]. The lowest numbers of amphipods occurred in July, 1985 (mean=1.33 \pm 0.52 (s.e.), $\mathrm{n}=15)$. Both Allorchestes angusta and the two species of Corophium showed the same general pattern of seasonal abundances, although, the number of $A$. angusta in algae was nearly twice that of Corophium spp. during fall and winter (Fig. 5). 
Annelids were the most abundant group of infauna. The pattern of abundance of polychaetes were opposite that of amphipods (Fig. 3). Polychaetes were more numerous in sediment below algae compared with algal mats (paired $\mathrm{f}=-3.753, \mathrm{D}<0.0001, \mathrm{n}=30$ ). There was no significant difference $(\mathrm{l}=1.278, \mathrm{p}<.2056, \mathrm{n}=70)$ in polychaete abundances in areas free of algae compared with sites covered with algae (mat and underlying sediment). The numbers of Streblospio benedicti were similar in sediment below algae and in the unvegetated samples, but were rarely abundant within algal mats (Fig. 6). The third most abundant animal was the polychaete, Capitella capitata. The mean numbers of $C$. capitata were similar in the algae, under the algae and in algal-free areas (Table 1). The number of oligochaete worms was greater within algal mats during May and July (Fig. 7). Oligochaetes, however, were significantly more abundant in algal mats compared with algal-free areas only in May $1985(\mathrm{t}=2.505, \mathrm{p}<0.05, \mathrm{n}=5)$.

Mean numbers of polychaetes among seasons was significantly different ( 2 factor ANOVA, $\mathrm{f}=2.368, \mathrm{p}<0.05, \mathrm{n}=7$ ). The seasonal pattern of polychaete abundance was similar to amphipods (Fig. 4). The greatest numbers of polychaetes occurred in October, 1984 and November, 1985, (Ryan's Q test, $\mathrm{CV}=25.968, \mathrm{D}=70, \mathrm{D}=0.05$ ) with the lowest numbers in summer, spring and winter.

\section{Algal Canopy}

There were significantly greater numbers of amphipods (up to 612/ 0.022 $\mathrm{m}^{2}$ forAllorchestes angusta) within the floating algal canopy compared with the underlying sediment $(\underline{U}=98, \underline{2}<0.001, n=20 ;$ Table 2). Qualitative observations 
of amphipod numbers from the water's surface to the sediment below indicated amphipods were almost exclusively in the top $10 \mathrm{~cm}$ of floating algal canopy.

The species composition and relative abundance of algal canopy amphipods were similar to those found on the intertidal mudflat (site $A$ ); Allorchestes angusta were most abundant, followed by Corophium spp. and Grandidierella japonica (only 2 specimens).

The only annelids found in sweep samples were oligochaetes, which were significantly more abundant in the sediment below algae than the algal canopy ( $\underline{U}=100, \underline{P}>0.001, \underline{n}=20 ;$ Table 2$)$.

\section{Field Experiment}

Large numbers of amphipods colonized the artificial substrates in the field experiment. The two most abundant amphipods found during field sampling, Allorchestes angusta and Corophium spp., also were the most abundant amphipods colonizing experimental substrates. Two other species of amphipods, Ampithoe valida and Grandidierella japonica, also colonized experimental substrates. The greatest numbers of amphipods were found in yarn [mean=238.7 \pm 134.4 (s.d.)]. The maximum number counted was 391 in one core on the second day of sampling. After two days in the field there was a significant difference in the numbers of amphipods colonizing the yarn compared with plastic strips and defaunated algae (Kruscal-Wallis, $H=5.422$, $\mathrm{p}<0.05, \mathrm{D}=9$ ).

The number of amphipods was significantly greater $(\underline{U}=81, \underline{2}<0.001, n=9)$ in natural algal mats than plots with algae removed (Fig. 9). Densities ranged 
from a mean of $6.3 \pm 4.5$ (s.d.) amphipods per core in the initial sample from the algal cleared site, to 0.0 on the third and fourth day of sampling (Fig. 9).

\section{Feeding Experiment}

In the laboratory feeding experiment, Allorchestes angusta consumed Enteromorpha spp. algae. Amphipods were observed chewing holes in the algal filaments under a dissecting microscope. Algal tissue also was found in the crops of amphipods following the feeding experiment. Weight of Enteromorpha spp. in the presence of $A$. angusta was significantly less than controls $(\underline{L}=25, \underline{2}<0.01, n=5)$. After 24 hours an average of $31.1 \%$ of algae weight was removed by amphipods, compared with an average weight loss of $2.7 \%$ in controls.

Crop contents of five Corophium spp. individuals, which had been placed with Enteromorpha spp. for 24 hours, contained no algae. 


\section{DISCUSSION}

\section{Community Structure}

The intertidal mudflats of Elkhorn Slough are largely covered by dense mats of several species of the green algae Enteromopha during spring and summer. Raven and Smith (1977) characterized Enteromorpha intestinalis (one of the abundant species in Elkhorn Slough) as a "sun" plant, adapted for

growth at near or full sunlight levels at the higher intertidal levels. The red alga Gracilaria lamanieformis, which replaced Enteromorpha spp. as the dominant alga on mudflats during fall and winter, was observed at lower tide levels during the rest of the year. This alga is typical of midtidal to subtidal areas (Abbott and Hollenberg, 1976).

The presence of these macroalgal mats greatly influences the distribution and abundance of amphipod crustaceans on the intertidal mudflats of Elkhorn Slough. Allorchestes angusta was clearly the most abundant amphipod in the study area. This motile, epifaunal amphipod was more abundant within the algae than elsewhere, throughout the year. The other common amphipods, Corophium acherusicum and $C$. insidiousum, are benthic tube-dwelling amphipods (pers. obs.; Conlan pers. comm.). Tubes of these amphipods were observed in the top $2 \mathrm{~cm}$ of underlying sediment in algal covered areas at lowtide on the intertidal mudflat. While sampling the floating Enteromorpha spp. at high-tide, I observed more than fifty tubes of juvenile Corophium spp. attached to algal thalli. This is the first documentation of algae being used as a place of attachment for Corophium tubes. Males of $C$. insidiosum emerge from their tubes to seek out receptive females during mating (Shillaker \& Moore, 1987). This may be one reason for finding Corophium abundant within algal mats. Hull 
(1987), however, found decreased numbers of Corophium volutator as Enteromorpha cover was experimentally increased. Corophium volutator was thought to be inhibited from burrowing through dense algae. The above study was in a eutrified area (area with sewage outflow) which had up to $3 \mathrm{~kg}$ wetweight $\mathrm{m}^{-2}$ of Enteromorpha spp. cover. This area was within an area of Spartina marsh, which is at a higher elevation than the present study and had a much denser cover of algae than the present study (maximum cover of 0.95 $\mathrm{kg}$ wet-weight $\mathrm{m}^{-2}$ : Appendix 1).

The effects of algal mats on invertebrates can vary greatly depending on the system. In a high elevation intertidal estuary, reduced species diversity and biomass of most infaunal invertebrates within Enteromorpha mats was observed, whereas, numbers of Hydrobia ulvae were greatly increased (Nicholls et al. 1981; Soulsby et al. 1982; Rosenberg 1985). In contrast, there was no significant difference in the abundance of infaunal polychaetes in areas with algal cover (algal mat and underlying sediment) compared with algal-free areas in Elkhorn Slough. However, in the this study, the number of polychaetes in the sediment below the algal mat was significantly higher than within the mat. In seagrass communities, Orth (1973) and Stoner (1980a) found an increased number of infaunal invertebrate species and biomass under vegetated compared with adjacent unvegetated areas. Seagrasses have extensive root systems which provide increased surface area for invertebrates. Seagrasses are also found at lower tidal elevations than the macroalgal mats, and do not experience the physical extremes in dessication and anoxic conditions found under algal mats. 
The spionid polychaete worm, Streblospio benedicti was the most numerous animal in this study. With the exception of May, 1985, it's seasonal pattern of abundance was similar in areas free of algae and in the sediment underlying the algae. In May, 1985, numbers were slightly higher within algal mats compared with algal-free areas. Streblospio benedicti is a surface deposite-feeding worm, which lives in the top few centimeters of substrate, extending it's palps into the water column to suspension feed when the current is strong (Levin, 1982). Juvenile and adult S. benedicti occasionally enter the water column (Levin, 1982), which may explain their presence within algal mats.

Mats of green macroalgae, including Enteromorpha spp. and Ulva spp., cause major perturbations to underlying benthic communities, especially during periods of low tide, poor water circulation, and warm weather. MacGinite (1935) described episodic mortality of macrofauna (including crustaceans, molluscs, and polychaetes) living in and under mats of Enteromorpha spp. during low tides, warm weather and high density of Enteromorpha in the Elkhorn Slough. A $\mathrm{pH}$ of 9.8 in an area of decaying Enteromorpha (compared with a pH of 8.5 in deep water) was attributed to the death of these animals (MacGinite 1935). Animals became entangled in the algae, preventing their escape. Munsen (1977) also described episodic mortalities of meiofauna living in and under an Enteromorpha mat during a warm day and low tide in Elkhorn Slough.

The physical stresses on fauna produced by dense Enteromorpha cover during low tides may explain some of the seasonal abundance patterns observed in this study. During spring and summer, when the algal mats were thickest, the sediment below mats was black, with a strong hydrogen sulfide 
smell indicating anoxic conditions. Numbers of amphipods and polychaetes also were at their lowest. Oligochaetes, however, reached their greatest numbers within the algal mats during May, the peak in Enteromorpha spp. cover. Oligochaetes are motile worms, which can move freely from sediment to algal mats, and are resistent to extreme conditions (Giere, 1979). Woodin (1974) reported at least two species of polychaetes, including Armandia brevis, dying of thermal stress when surface-sediment temperatures reached $28.4^{0} \mathrm{C}$. In April 1985, of this study, the surface sediment temperature on the mudflat in Elkhorn Slough reached $28^{\circ} \mathrm{C}, 2 \mathrm{~cm}$ into the sediment below the algal mat (although these measurements were not well quantified). Nicholls et al. (1981) found that the biomass of invertebrates within the sediment under thick algal mats (10-12 cm deep), was greatly restricied in the number of species. He found oligochaetes and two species of polychaetes (including Capitella capitata) were the only fauna found in any abundance.

\section{Habitat Structure}

The value of the physical structure of algal mats was idicated in the colonization experiment, when high numbers of amphipods colonized synthetic yarn. The numbers of amphipods colonizing defaunated natural algae were not statistically different from those in plastic strips. The very large numbers of amphipods in yarn may indicate a preference for a denser, more complex habitat than either natural algae or plastic strips. Yarn and plastic had no nutritional value for amphipods. Furthermore, it is unlikely that the substrates were colonized by bacteria or other microrganisms in sufficiently high numbers in twenty four hours to attract amphipods. 
The complexity of algal substrates in attracting amphipod colonization may be important. Pomeroy and Levings (1980) reported the amphipod Eogammarus confervicolus showed a preference for more filamentous forms of green algae, such as Enteromorpha linza compared to thallose forms such as Ulva lactuca. The beneficial aspect of protective cover in algal-invertebrate associations, especially epifaunal crustaceans, was demonstated along the rocky shore (Moore 1977; Arrontes \& Anadon 1990). Weiser (1952), found algae with large surface areas (e.g. tufted Gelidium corneum) harbored more invertebrate species than species with flattened thalli, like Porphyra laciniata along the rockyshore. Densities of crustaceans, particularly the amphipod Ampithoe tea, were positively correlated with size and complexity of algae on the rocky shore (Gunnill, 1983). The amphipod Ampithoe valida secretes mucus to "glue" algae, such as Enteromorpha spp. or Ulva spp., blades together to form a tube (pers. obs., Conlan pers. comm.).

In vegetated areas, such as seagrass beds, an important function of the grasses to associated organisms is offering shelter and a substate for attachment (Kikuchi 1980). Stoner (1980b) found the surface area of seagrass blades determined the habitat selection of three species of amphipods, which was related to predator avoidance. The extensive cover of algal mats on the intertidal mudflats of Elkhorn Slough, may offer amphipods protection from at least some of the shorebirds feeding on these mudflats. Most shorebirds actively avoided areas covered with thick green algal mats during feeding (Tubbs and Tubbs,1980 and Nicholls et al.,1981). The numerically dominant shorebird found along Elkhorn Slough throughout the year is the Western Sandpiper, which feeds extensively on Corophium spp. amphipods during 
winter (Ramer et al. 1991). My qualitative observations in Elkhorn Slough, indicated that small shorebirds, such as sandpipers, avoided areas with dense algal cover.

\section{Enteromorpha as a Food Source}

The most abundant amphipod in this study, Allorchestes angusta fed on Enteromorpha spp. in a laboratory experiment. Allorchestes angusta is an epifaunal, motile amphipod that gnaws holes in the algae during feeding. Several gammarid amphipods consume Enteromorpha (Martin 1965, Pomeroy \& Levings 1980). Nicotri (1980) found that Enteromorpha spp. ranked fifth (in 18 species) in both attractiveness and edibility for the amphipod Ampithoe valida, which was also present in this study. Amphipods may have a significant effect on the distribution and abundance of green algal mats (Warwick et al 1982). Based on laboratory and field experiments, Price and Hylleberg (1982) estimated that the amphipod Eogammarus confervicolus could consume over half of the annual net production of Ulva mats in False Bay, Washington.

Corophium insidiosum and $C$. acherusicum are classified as selective deposit feeders (Meadows 1964, Meadows \& Reed 1966, Fenchel et al. 1975, Kofoed \& Lappalainen 1975). Examination of the crop contents of Corophium spp. indicated they were not feeding on algae, but likely eat the abundant detritus within algal mats. Enteromorpha mats are highly productive systems with an estimated annual primary production ranging from 270 to 1100 grams carbon m-2 yr-1 (Shellem \& Josselyn 1982, Pregnall \& Rudy 1985). The structure of algal filaments increases sedimentation in algal mats, producing high levels of dissolved organic matter (Pregnall \& Rudy 1985). Amphipods 
such as Allorchestes angusta, likely breakdown the algae through their grazing, whereas detritivores, like Corophium spp., consume the resulting detritus.

\section{Conclusions}

1) Polychaete worm numbers were not significantly different in areas covered with algae (algal mat \& underlying sediment) compared with algal-free areas.

2) Amphipod crustacean numbers were significantly higher within algal mats compared with the sediment below the mats and algal-free areas.

3) Amphipods were more numerous in algae compared to underlying sediment and algal-free areas at low tide on the intertidal mudflats and in the floating Enteromorpha spp. canopy.

4) Amphipods colonized artificial substrates (with no nutritional value) in high numbers indicating the value of the algal mats as a structural habitat.

5) The amphipod Allorchestes angusta feeds on Enteromorpha spp. algae. 


\section{LITERATURE CITED}

Abbott, I.A. \& G.J. Hollenberg. 1976. Marine Algae of California. Stanford University Press. Stariford, CA. 827 pp.

Arrontes J. and R. Anadon. 1990. Distribution of intertidal isopods in relation to geograhical changes in macroalgal cover in the bay of Biscay. J. mar. biol. Ass. U.K., 70: 283-293.

Bliding, C. 1963. A critical survey of European taxa in Ulvales. I. capsosiphon, percursaria, Blidingia, Enteromorpha. Bot. Notiser (Suppl.) Opera Botanica, 8(3): 1-160.

Browning B. M. 1972. The Natural Resources of Elkhorn Slough their present and future use. Coastal Wetland Series \#4 105 pp.

Day, R. W. and G. P. Quinn, 1989. Comparisons of treatments after an analysis of variance in ecology. Ecological Monographs, 59(4): 433-463.

Edgar, G. J., 1990. The influence of plant structure on the species richness, biomass and secondary production of macrofaunal assemblages associated with Western Australia seagrass beds. J. Exp. Mar. Biol. Ecol. 137: $215-240$.

Everett, R. A., 1991. Intertidal distribution of infauna in a central California lagoon: the role of seasonal blooms of macroalgae. J. Exp. Mar. Biol. Ecol., 150: $223-247$.

Fenchel, T., L. H. Kofoed and A. Lappalalnen. 1975. Particle size-selection of two deposit feeder: the amphipod Corophium volutator and the Prosobranch Hydrobia ulvae. Marine Biology 30: 119-128.

Giere, O.W. 1979. Tolerance and preference reactions of marine Oligochaeta in relation to their distribution. In Aquatic Oligochaete Biology. R. $O$ Brinkhurst and D. G. Cook eds. Plenum Press, New York \& London. p. 385-409.

Gunnill, F. C. 1983. Seasonal variations in the invertebrate faunas of Pelvetia fastigiata (Fucaccae): Effects of plant size and distribution. Marine Biology 73: 115-130.

Heck, K. L. Jr. and R. J. Orth. 1980. Structural components of eelgrass (Zostera marina) meadows in the lower Chesapeak Bay-decapod crustacea. Estuaries. 3: 289-295. 
Hull, S. C. 1987. Macroalgal mats and species abundance: a field experiment. Estuarine, Coastal and Shelf Science 25: 519-532.

Hulbert, S. H. 1984. Pseudoreplication and the design of ecological field experiments. Ecological Monographs, 54(2): 187-211.

Kikuchi, T. 1980. Faunal relationships in temperate seagrass beds. In Handbook of Seagrass Biology: An Ecosystem Perspective. R. C. Phillips and C. P. McRoy. New York: Garland S T P M Press. p.153-171.

Kitting, C. L., B. Fry and M. D. Morgan. 1984. Detection of inconspicuaous epiphytic algae supporting fod webs in seagrass meadows. Oceologia 62: 145-149.

Kofoed, L. H. and A Lappalainen. 1975. Particle size-selection of two deposite feeders: the amphipod Corophium volutator and the prosobranch Hydrobia ulvae. Marine Biology 30: 119-128.

Levin, L. A. 1982. Interference interactions among tube-dwelling polychaetes in a dense infaunal assemblage. J. Exp. Mar. Biol. Ecol., 65: 107-119.

Leving, C. D. 1980. The biology and energetics of Eogammarus confervicolus (Stimpson) at the Squamish River Estuary, B.C. Can. J. zool. 58: $1652-1663$.

MacGinite, G. E. 1935. Ecological aspects of a California marine estuary. The American Midland Naturalist. 16; 5: 629-700.

Martin, A. L. 1965. Feeding and digestion in two intertidal gammarids: Marinogammarus obstusatus and M. Pirloti. J. Zool. 148: 515-525.

Meadows, P. S. 1964. Experiments on substrate selection by Corophium species: films and bacteria on sand particles. J. Exp. Biol. 41: 499-511. Meadows, P.S. and A. Reid. 1966. The behavior of Corophium volutator (Crustacea: Amphipoda). J. Lond. 150: 389-399.

Munsen, D. A. 1977. An analysis of some of the factors affecting the distribution of the metazoan fauna in a California estuarine sulfide ecosystem. Ph.D. Dissertation, Stanford University. 288 pp.

Moore, P. G. 1977. Organization in simple communities: observations on the natural history of Hyale nilssoni (amphipoda) in high littoral seaweeds. $p$ 443-451 In: "Biology of benthic organisms. Keegan B. F., O'Ceidigh (eds.).Pergamon press. 
Nicholls, D. J. , C. R. Tubbs and F. N. Haynes. 1981. The effect of green algal mats on intertidal macrobenthic communities and their predators. Kieler Meeresforsch., Sonderh. 5: 511-520.

Nicotri, M.E. 1980. actors involved in herbvivore food preference. J. exp. Mar. Biol. Ecol.,42: 13-26.

Norris, J. N. 1970. Studies on the taxonomy and distribution of some Ulvales from Elkhorn Slough, California. Masters thesis California State University. $102 \mathrm{pp}$.

Nybakken, J. W., G. Cailliet and W. W. Broenkow. 1977. Ecologic and hydrologic studies of Elkhorn Slough, Moss Landing Harbor and nearshore coastal waters, July 1974-June 1976. Moss Landing Marine Labs, Moss Landing, CA, 464 pp.

Orth, R.J., K.L. Hick Jr. and J. VanMontfrans. 1984. Faunal communities in seagrass beds: A review of the influence of plant structure and prey predator-prey relationships. Estuaries 76 (4a): 339-350.

Pomeroy, W.M. and C.D. Levings. 1980. Association and feeding relationships between Eogammarus confervicolus (Amphipoda, Gammaridae) and benthic algae on Sturgeon and Roberts Banks, Fraser River Estuary. Can. J. Fish. Aquat. Sci. 37: 1-10.

Pregnall, A. M. and P. P. Rudy. 1985. Contribution of green macroalgal mats Enteromorpha spp.) to seasonal production in an estuary. Mar. Ecol. Prog. Ser. 24: 167-176.

Price, L.H. and J. Hylleberg. 1982. Algal-faunal interactions in a mat of Ulva fenestrata in False Bay, Washington. Ophelia. 21(1): 75-88.

Ramer, B.A., Page, G.W. \& Yoklavich M.M. 1991. Seasonal abundance, habitat use, and diet of shorebirds in Elkhorn Slough, California. Western Birds 22:157-174.

Raven, J. A. and F. A. Smith. 1977. "Sun" and "Shade" species of green algae: Relation to cell size and environment. Photosynthetica. 11: 48-55.

Rosenberg, R. 1985. Eutrophication-the future marine coastal nuisance? Mar. Poll. Bull. 16 (6): 227-231.

Shellem, B. H. and M. N. Josselyn. 1982. Physiological ecology of Enteromorpha clathrata (Roth) Grev. on a salt marsh mudflat. Botanica Marina. 25: 541-549. 
Shillaker, R. O. \& P. G. Moore, 1987. Tube-emergence behaviour in the amphipods Lembos websteri Bate and Corophium bonnellii Milne Edwards. J. Exp. Mar. Biol. Ecol. 111: 231-241.

Soulsby, P. G., D. Lowthion and M. Houston. 1982. Effects of macroalgal mats on the ecology of intertidal mudflats. Mar. Poll. Bull. 13 (5): 162-166.

Smith, R.I. and J.T. Carlton. 1975. Light's Manual Univ. of Cal. press. 717 pp.

Stoner, A. W. 1980a. The role of seagrass biomass in the organization of benthic macrofaunal assemblages. Bull. Mar. Sci. 30: 537-551.

Stoner, A. W. 1980b. Perception and choice of substratum by epifunal amphipods associated with seagrasses. Mar. Ecol. Prog. Ser. 29: $279-288$.

Summerson, H. C. and C. H. Peterson. 1984. Role of predation in organizing benthic communities of a temperate-zone seagrass bed. Mar. Ecol. Prog. Ser. 15: 63-77.

Tubbs, C. R. and J. M. Tubbs. 1983. Macroalgal mats in Langstone harbour, Hampshire, England. Mar. Poll. Bull. 14 (4): 162-166.

Virnstein, R. W. 1978. Predator caging experiments in soft sediments: caution advised. In: Estuarine Interactions. pp. 261-273.

Virnstein, R. W., P. S. Mikkelsen, K. D. Cairns and M. S. Capone. 1983. Seagrass beds versus sand bottoms: the trophic importance of their associated benthic invertebrates. Florida Sci. 46: 363-381.

Warwick, R. M., J. T. Davey, J. M. Gee and C. L. George. 1982. Faunistic control of Enteromorpha blooms: a field experiment. J. exp. mar. Biol.Ecol. 56: 23-31.

Wieser, W. 1952. Studies on the vertical distribution of the fauna inhabiting seaweeds below the Plymouth laboratory. Mar. Biol. Assoc. 31: 145-172.

Woodin, S. A. 1974. Polychaete abundance patterns in a marine softsediment environment: the importance of biological interactions. Ecol. Monogr. 44: 171-187.

Zimmerman, R.J. \& T.J. Minello. 1984. Densities of Penaeus aztecus, $P$. setiferus, and other natant macrofauna in a Texas salt marsh. Estuaries. $7(4 A): 421-433$. 
Table 1. Listed are the most abundant taxa of benthic invertebrates living within algal mats $(n=35)$, under algal mats $(n=35)$ and in algal-free mudflats $(n=35)$. Data are total number of individuals from all samples taken from each of the three habitats with means [ \pm standard deviations in ()], from June 1984 to November 1985. Ranks are according to greatest numbers.

\begin{tabular}{|c|c|c|c|c|c|}
\hline & $\begin{array}{l}\text { Within } \\
\text { Algae }\end{array}$ & $\begin{array}{l}\text { Under } \\
\text { Algae }\end{array}$ & $\begin{array}{l}\text { Algal- } \\
\text { Free }\end{array}$ & $\begin{array}{l}\text { Total } \\
\text { Number }\end{array}$ & Rank \\
\hline \multicolumn{6}{|l|}{ Crustaceans } \\
\hline \multicolumn{6}{|l|}{ Amphipods } \\
\hline Allorchestes angusta & $\begin{array}{c}28.47 \\
(34.09)\end{array}$ & $\begin{array}{c}4.42 \\
(6.58)\end{array}$ & $\begin{array}{c}1.94 \\
(3.29) \\
\end{array}$ & 1202 & 4 \\
\hline Corophium spp. & $\begin{array}{c}14.23 \\
(13.47)\end{array}$ & $\begin{array}{c}4.13 \\
(5.9)\end{array}$ & $\begin{array}{c}6.30 \\
(11.22)\end{array}$ & 820 & 5 \\
\hline Grandidierella japonica & $\begin{array}{c}1.61 \\
(3.39) \\
\end{array}$ & $\begin{array}{c}0.67 \\
(1.59) \\
\end{array}$ & $\begin{array}{c}0.62 \\
(1.12) \\
\end{array}$ & 112 & 10 \\
\hline Ostracods & $\begin{array}{c}1.89 \\
(2.56) \\
\end{array}$ & $\begin{array}{c}0.61 \\
(0.97) \\
\end{array}$ & $\begin{array}{c}0.64 \\
(1.42) \\
\end{array}$ & 130 & 7 \\
\hline \multicolumn{6}{|l|}{ Polychaetes } \\
\hline Streblospio benedicti & $\begin{array}{c}9.9 \\
(10.43)\end{array}$ & $\begin{array}{c}31.83 \\
(26.10) \\
\end{array}$ & $\begin{array}{c}32.71 \\
(32.69)\end{array}$ & 2,981 & 1 \\
\hline Capitella capitata & $\begin{array}{c}11.8 \\
(17.78) \\
\end{array}$ & $\begin{array}{c}12.62 \\
(10.58)\end{array}$ & $\begin{array}{c}18.11 \\
(26.75)\end{array}$ & 1,426 & 3 \\
\hline Polydora spp. & $\begin{array}{c}2.89 \\
(5.14)\end{array}$ & $\begin{array}{c}7.23 \\
(13.16)\end{array}$ & $\begin{array}{c}7.97 \\
(15.26) \\
\end{array}$ & 633 & 6 \\
\hline Eteone californica & $\begin{array}{c}0.79 \\
(1.43) \\
\end{array}$ & $\begin{array}{c}0.80 \\
(1.45) \\
\end{array}$ & $\begin{array}{c}1.27 \\
(1.25) \\
\end{array}$ & 128 & 8 \\
\hline Armandia brevis & $\begin{array}{c}0.91 \\
(2.09) \\
\end{array}$ & $\begin{array}{c}0.4 \\
(0.68) \\
\end{array}$ & $\begin{array}{c}0.97 \\
(2.16) \\
\end{array}$ & 115 & 9 \\
\hline Oligochaeta & $\begin{array}{c}32.27 \\
(46.70) \\
\end{array}$ & $\begin{array}{c}19.32 \\
(20.16) \\
\end{array}$ & $\begin{array}{c}34.6 \\
(26.75) \\
\end{array}$ & 2,275 & 2 \\
\hline
\end{tabular}


Table 2. Mean number of macrofauna $( \pm s . d ., n=10$ ) from sweep samples in algal canopy compared to underlying sediment in June 1989.

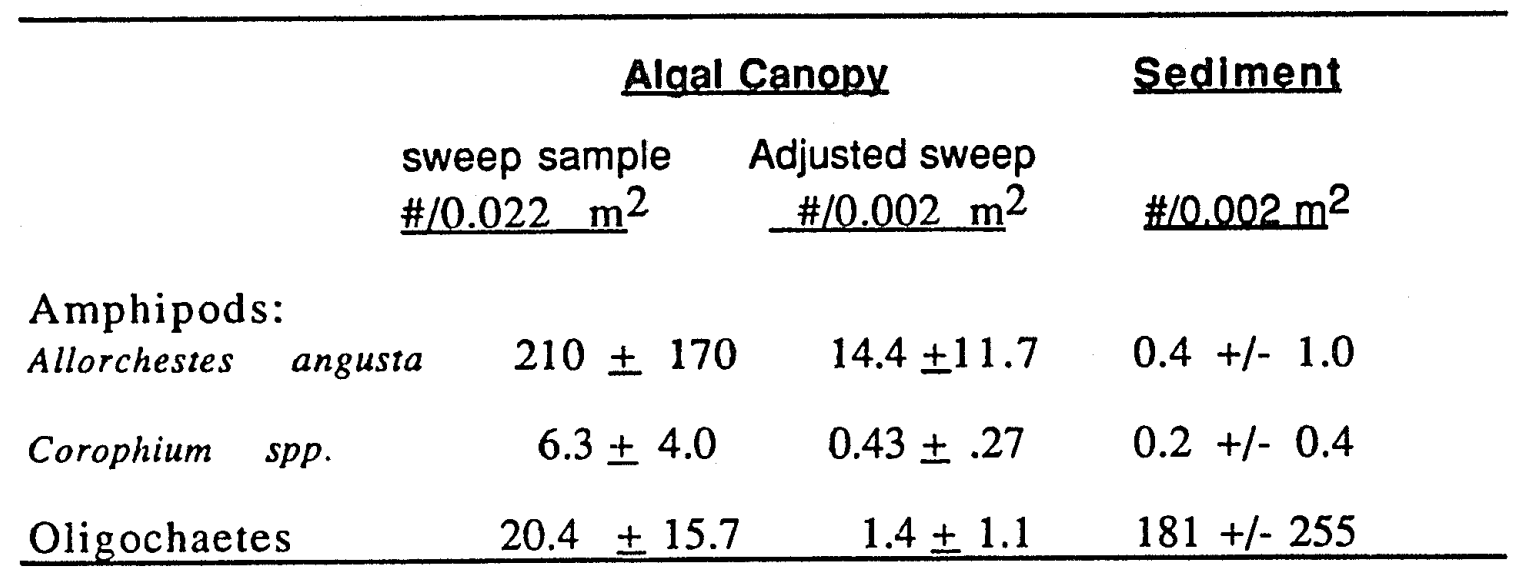


FIGURE 1. Map of Elkhorn Slough indicating study sites A and $B$ within the Elkhorn Slough National Estuarine Research Reserve and site $c$ at Kirby Park.

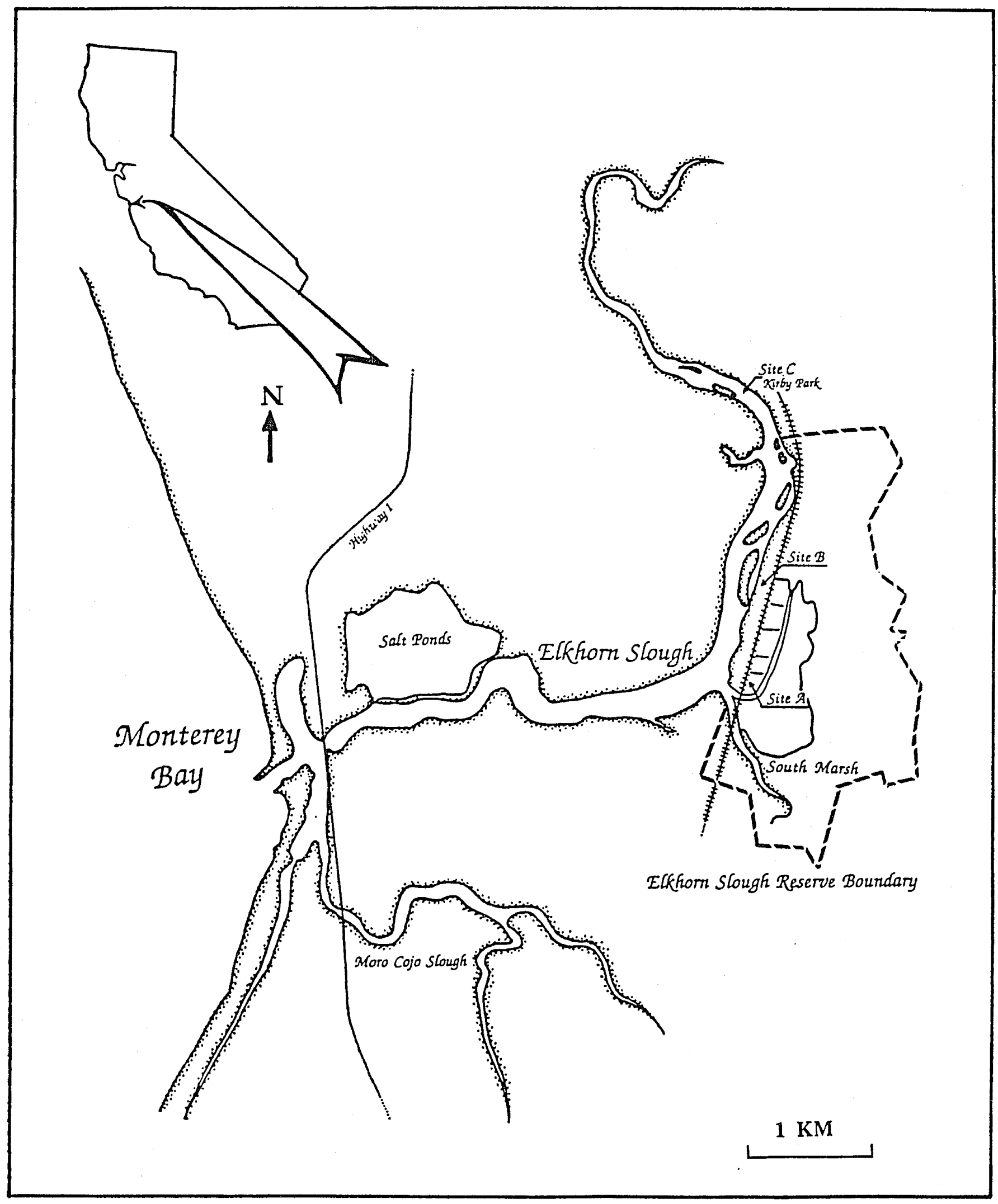




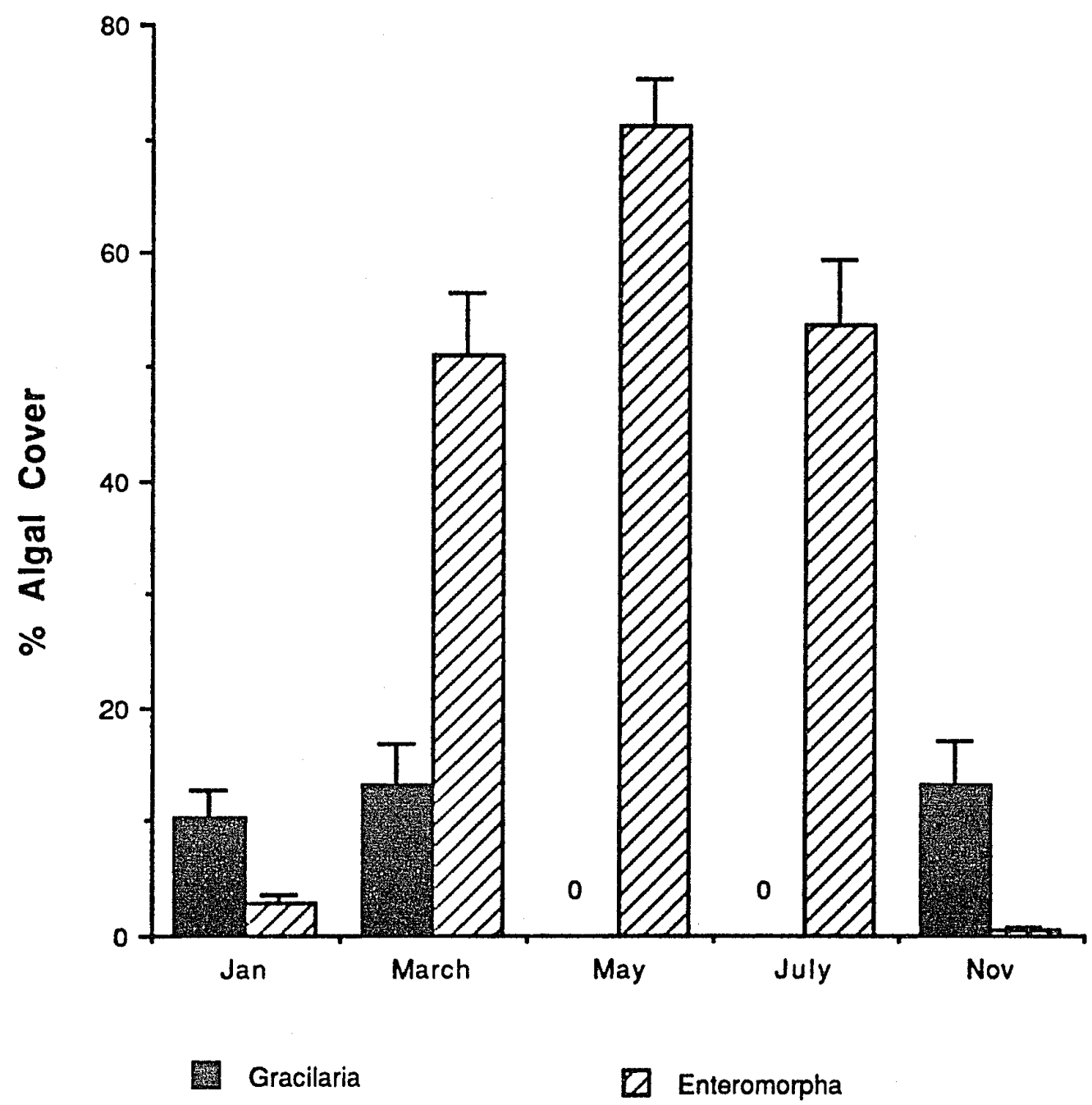

Figure 2. Percent macroalgal cover on the mudflat from January to November, 1985. Means based on fifty quadrats per datum. 


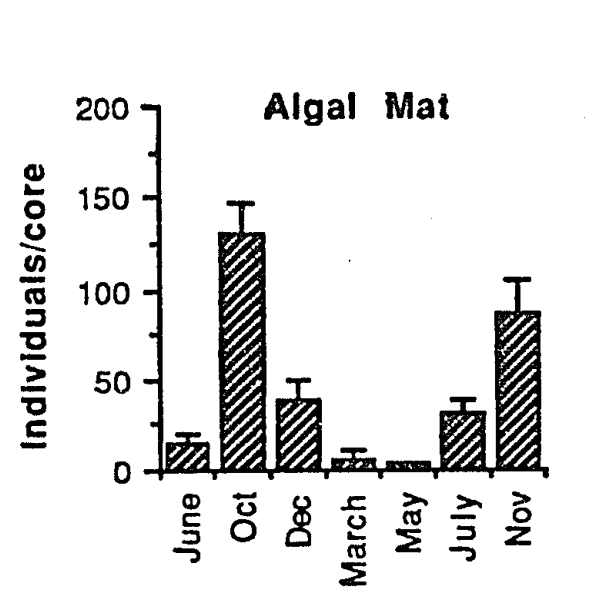

\section{Amphipod abundance}
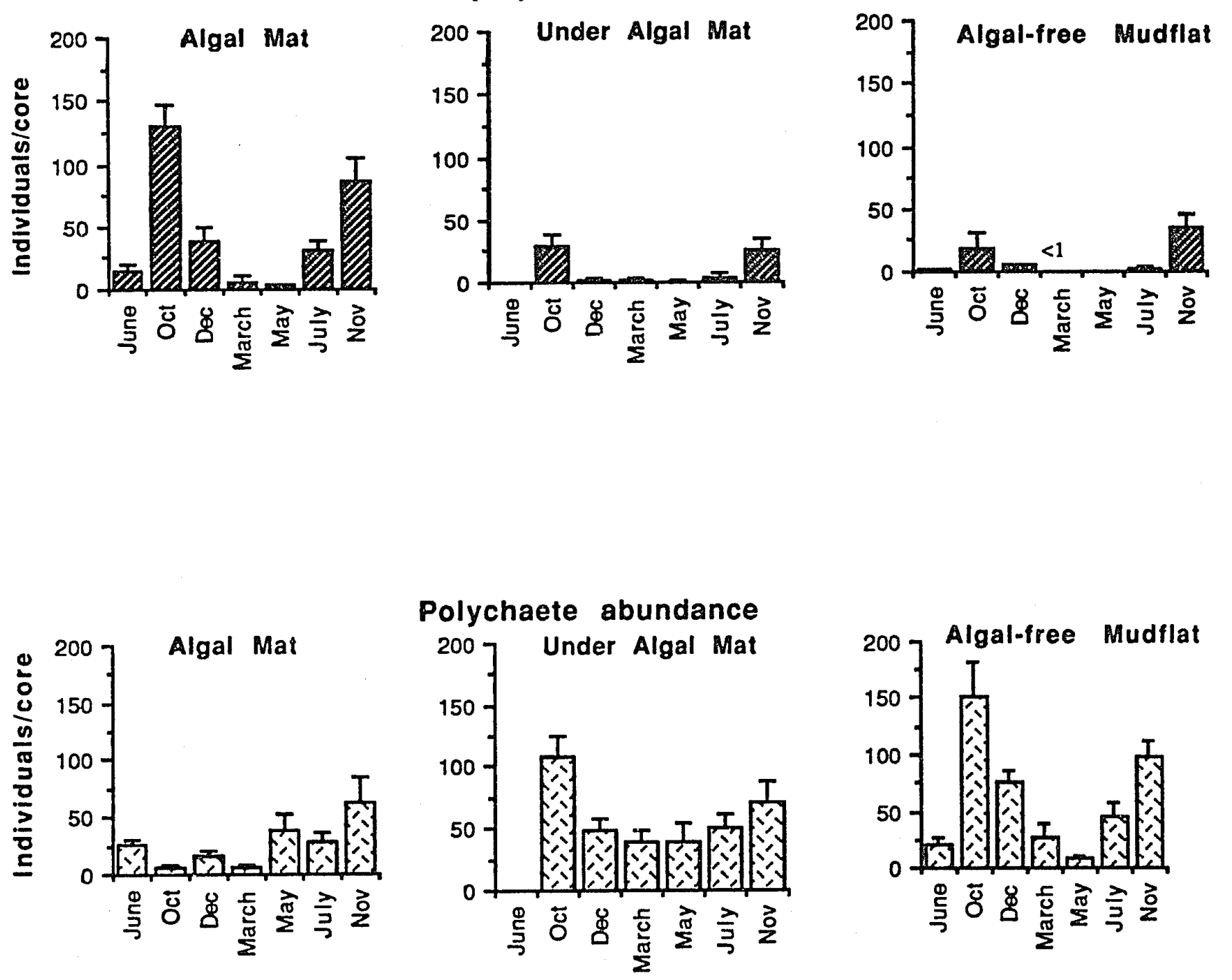

Figure 3. Number of amphipod crustaceans and polychaete worms within the algal mat, underneath algal mat and in algal-free mudflat from June 1984 to Nov. 1985. Each datum is a mean and one standard error based on 5 replicate cores. Note: * Samples of algal mat and underlying sediment were not separated in June 1984. 
Seasonal Abundance of Amphipods and Polychaetes

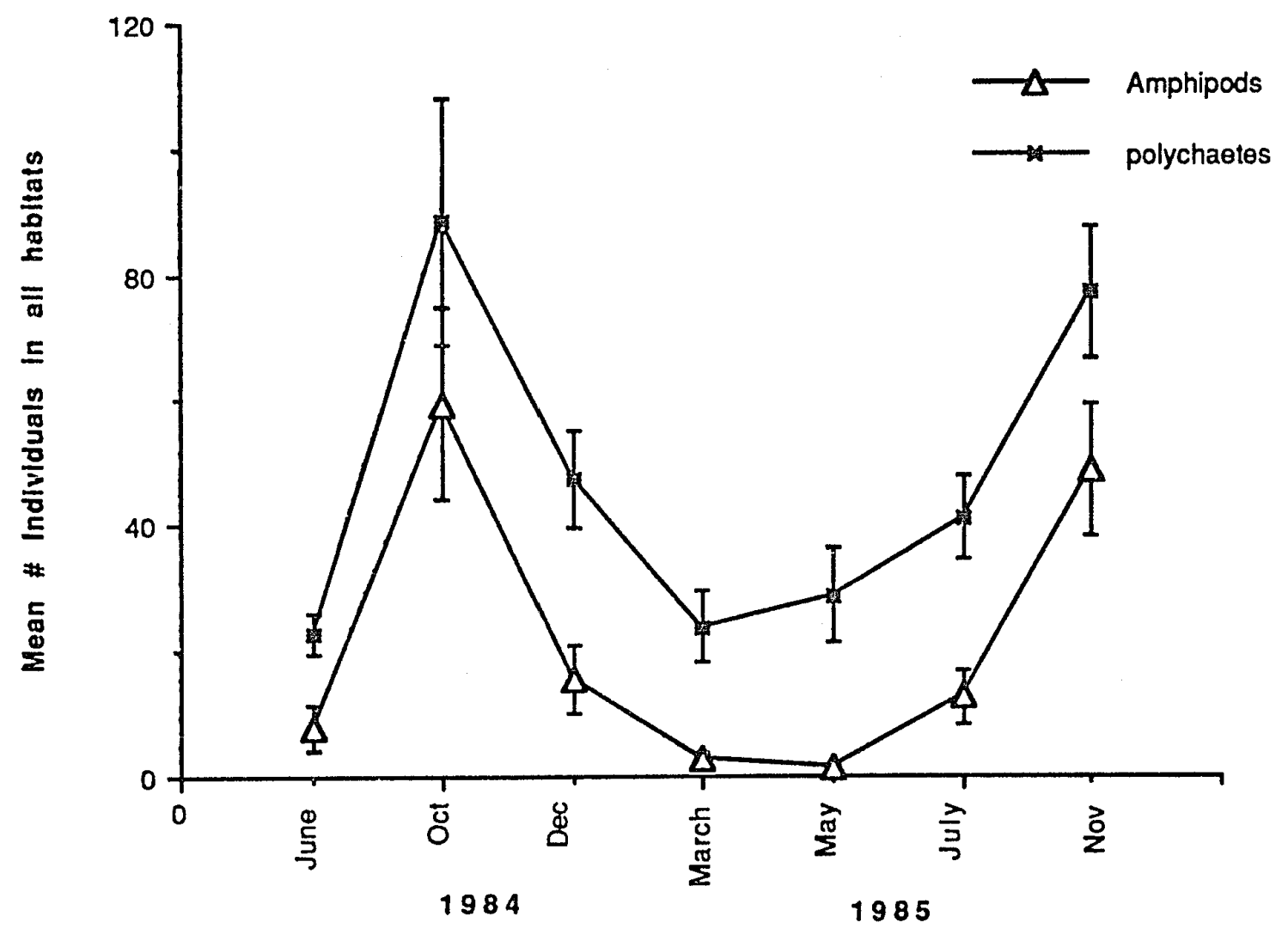

Figure 4. Abundances of amphipods and polychaetes within all habitats from June 1984 to November 1985. Each datum is a mean and standard error based on 15

replicate cores (except June: $n=10$ ) taken within algae, underneath algae and in algalfree areas. 

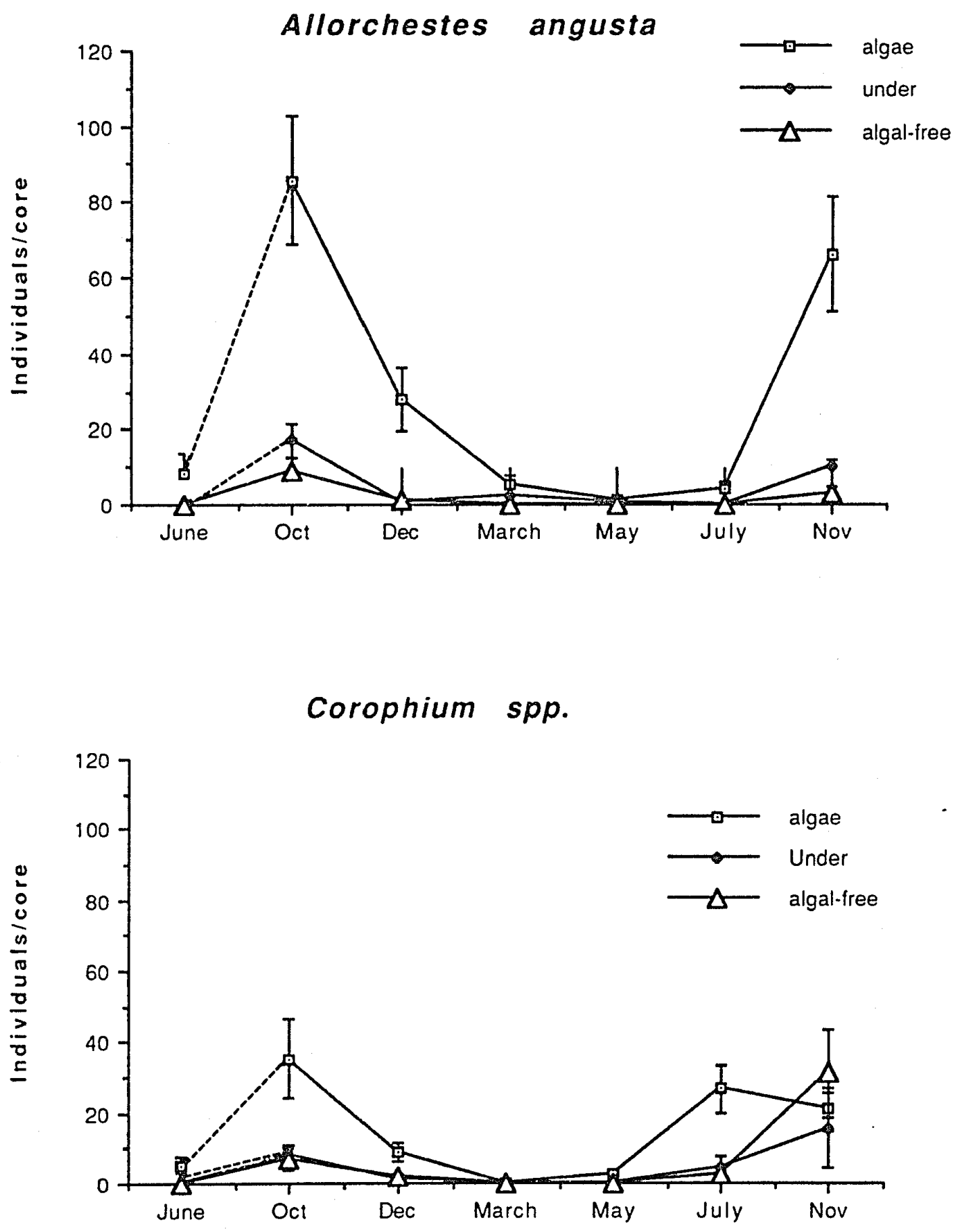

Figure 5. Number of Allorchestes angusta and Corophium spp. within the algal mat, underneath algal mat and in algal-free mudflat. Each datum is a mean and one standard error based on five replicate cores. Note: the algal mat was not separated from the underlying sediment in June 1984. 

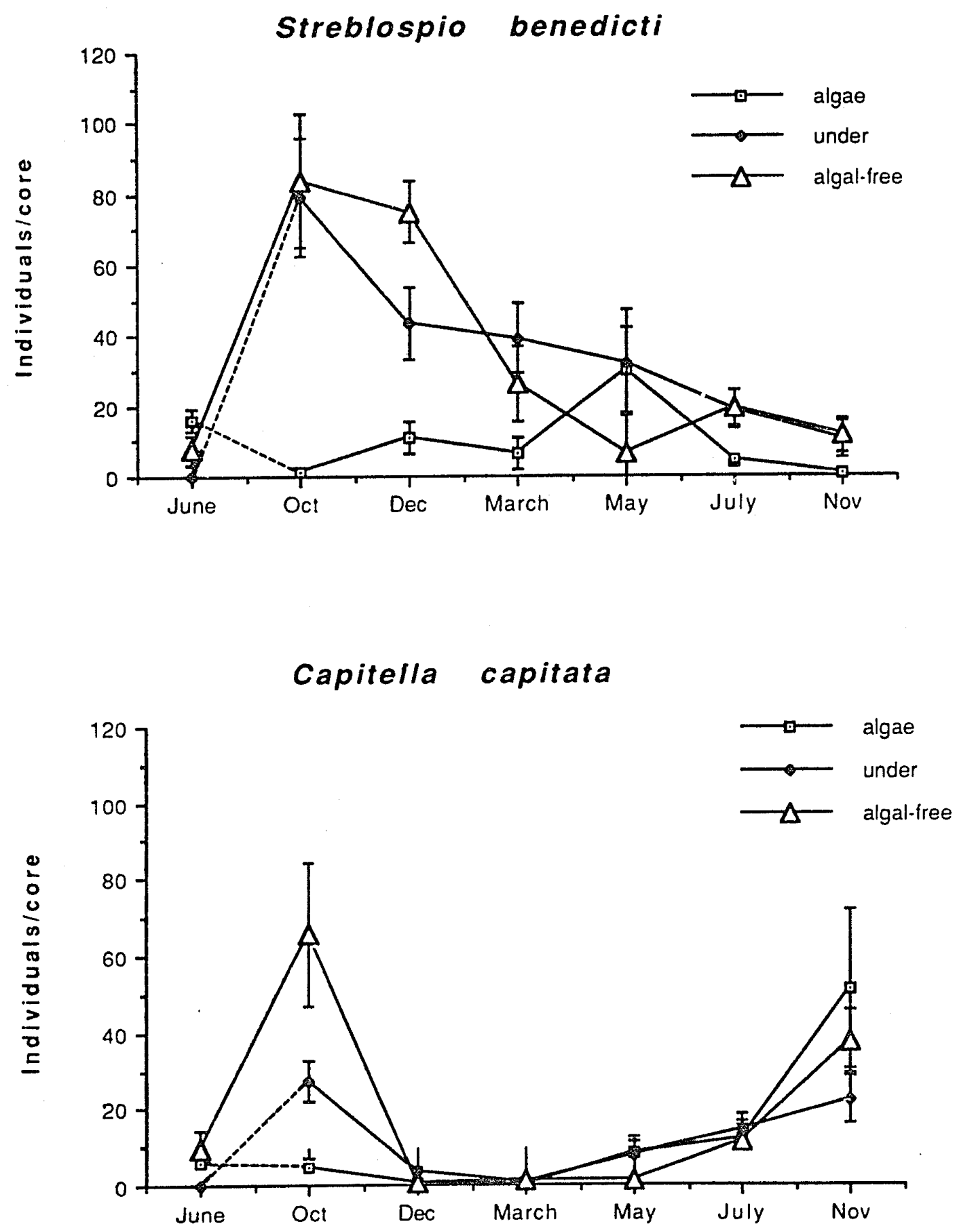

Figure 6. Number of Streblospio benedicti and Capitella capitata (polychaete worms) within the algal mat, underneath algal mat and in algal-free areas of the mudflat. Each datum is a mean and one standard error based on five replicate cores. Note: the algal mat was not separated from the underlying sediment in June 1984. 


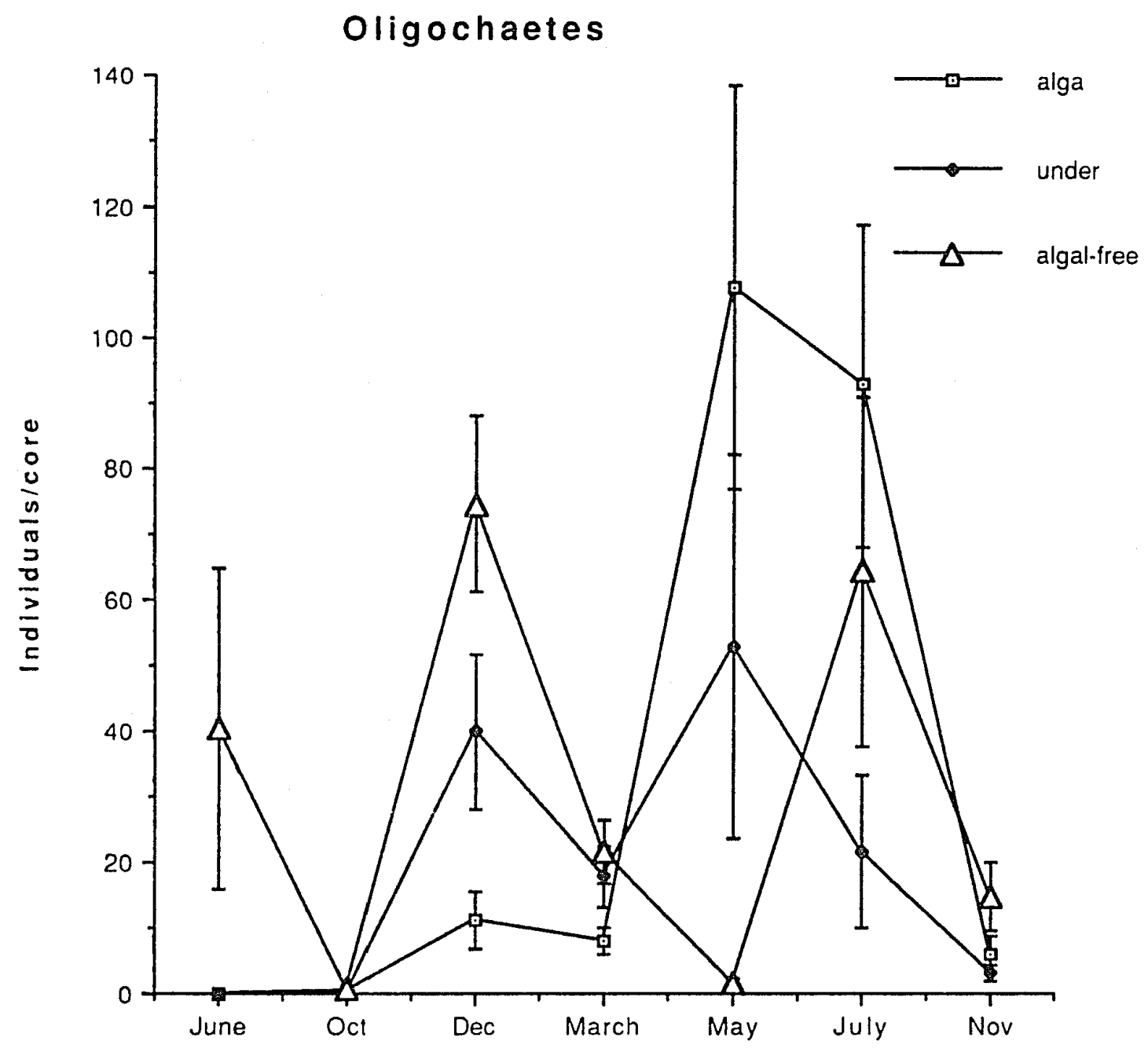

Figure 7. Number of oligochaete worms within the algal mat, underneath algal mat and in algal-free areas of the mudflat. Each datum is a mean and one standard error based on five replicate cores. note: The algal mat was not separated from the underlying sediment in June 1984. 


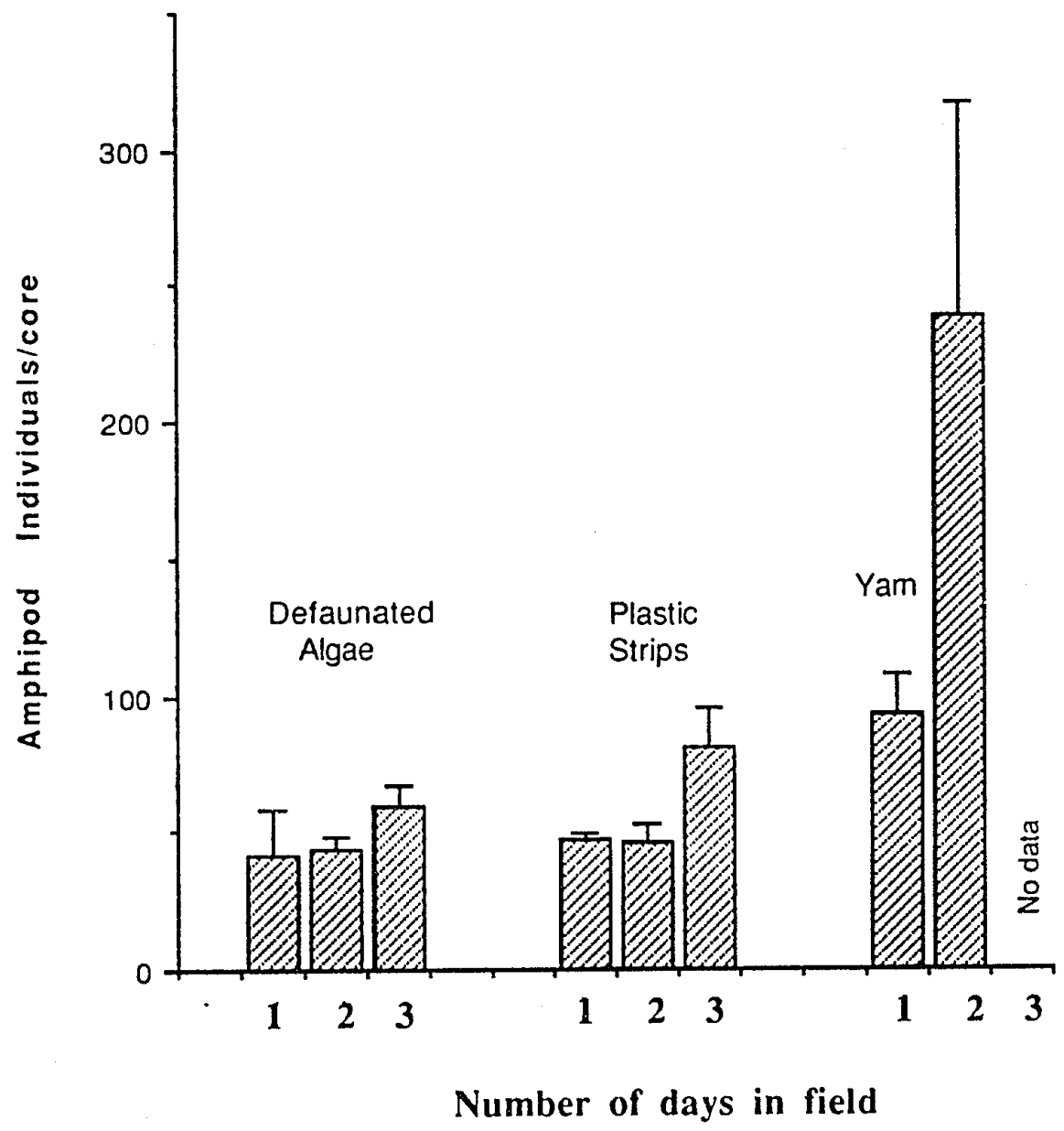

Figure 8. Amphipod colonization of defaunated natural algae, plastic strips and yarn, which were placed on an algal-free mudflat for 4 days in November 1987 (also see Figure 9). Each datum is a mean and one standard error based on 3 replicate experimental treatments. 


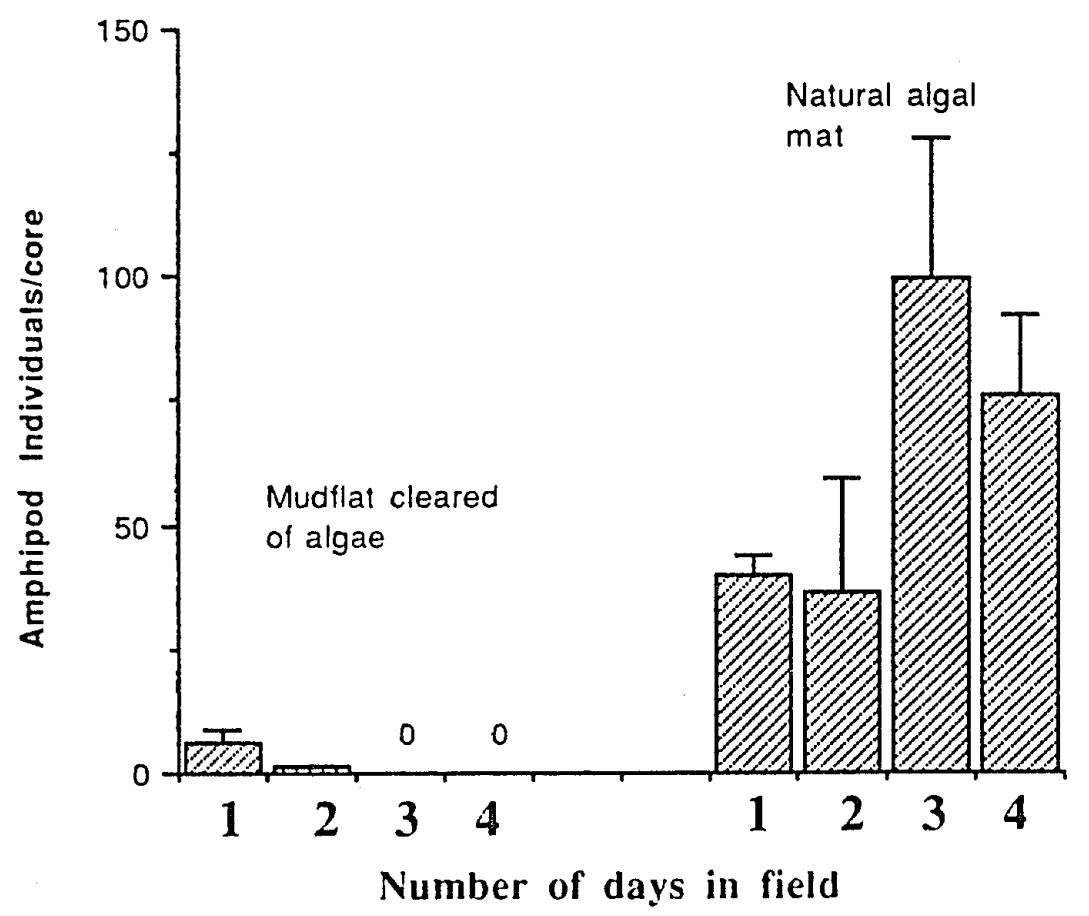

Figure 9. Amphipod colonization of mudflat where algal mat was experimentally removed and amphipod numbers in natural algal mat during the 4 day field experiment (see also Figure 8). Each datum is a mean and one standard error based on 3 replicate experimental treatments. 
Appendix 1. Enteromorpha Wet Weights

\begin{tabular}{|c|c|c|}
\hline Month & $\begin{array}{l}\text { Mean weight in } \\
\text { grams }( \pm \text { s.d. }) \mathrm{n}=5 \\
\text { area }=.002 \mathrm{~m}^{2}\end{array}$ & $\begin{array}{c}\text { Weight converted } \\
\text { to } \mathrm{Kg} \mathrm{m}-2\end{array}$ \\
\hline March '85 & $.8524 \pm .2259$ & .425 \\
\hline May '85 & $1.934 \pm 1.016$ & .950 \\
\hline July '85 & $.9530 \pm .3419$ & .4765 \\
\hline
\end{tabular}

